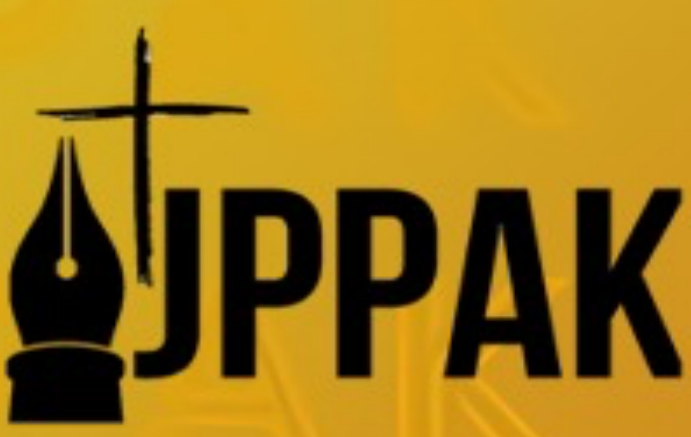

\title{
E-ISSN: 2774-4094
}

JURNAL
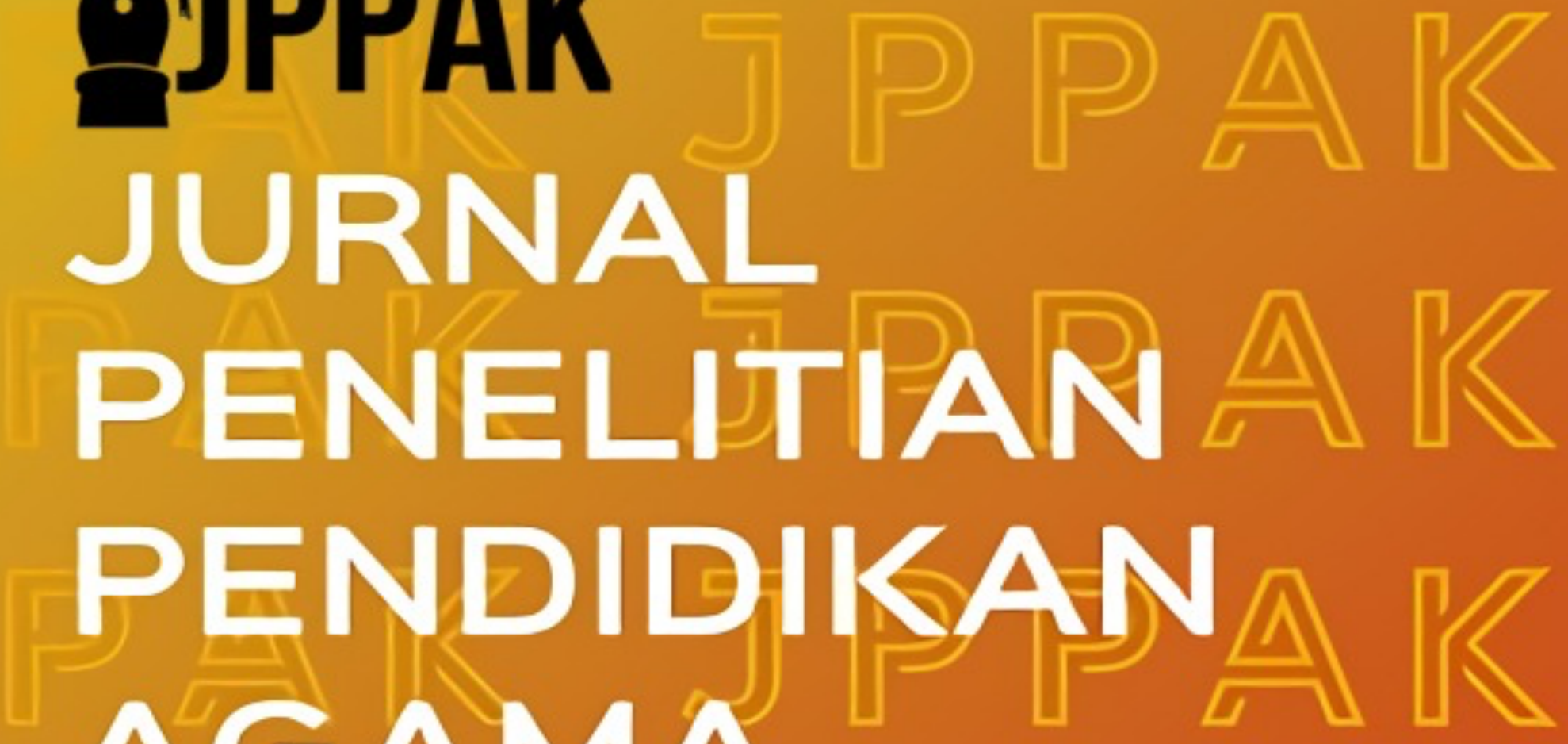

AGAMA
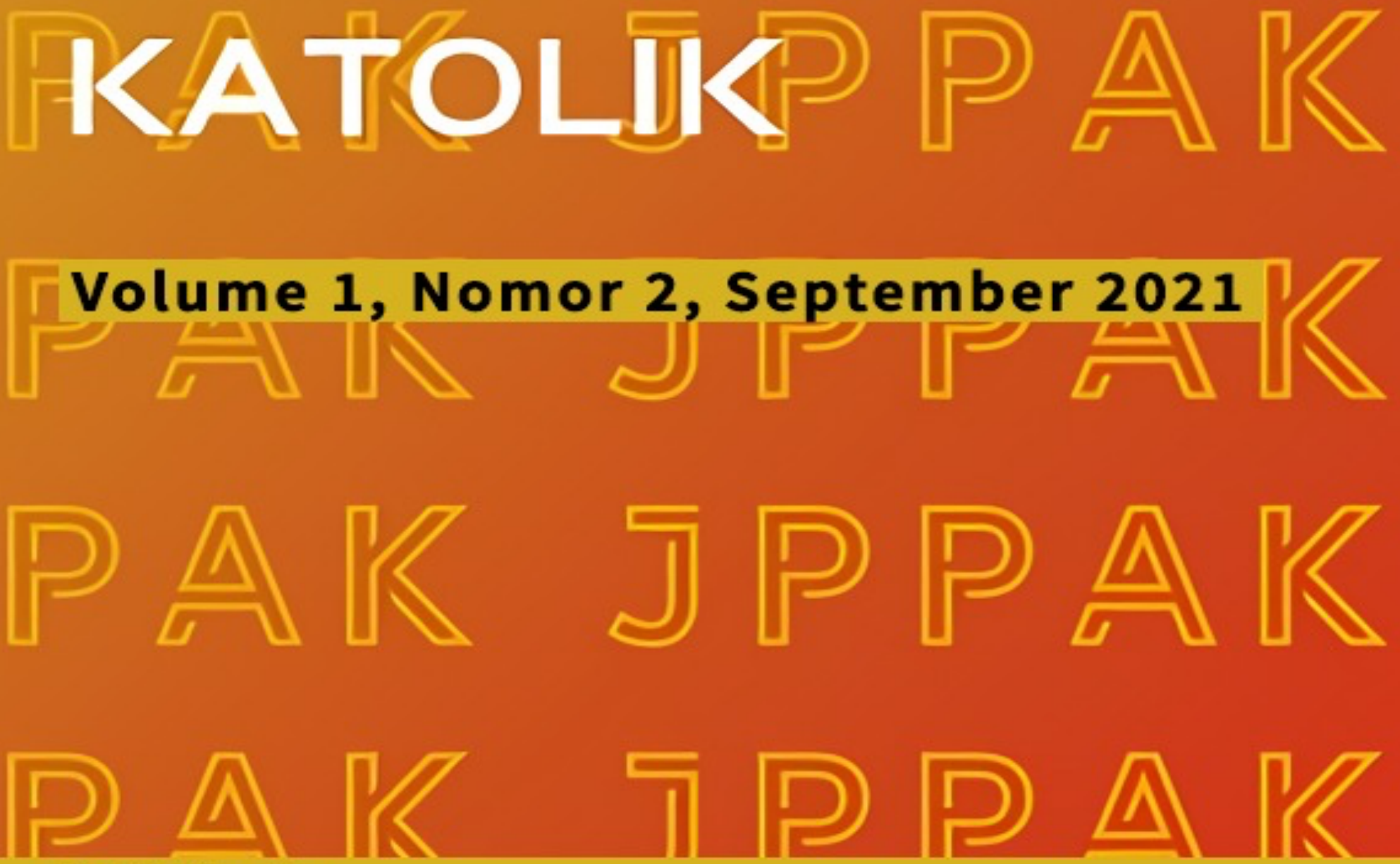

Published by

PERPETAKI

Perkumpulan Perguruan Tinggi Agama Katolik

\redaksi@jurnalppak.or.id @https://jurnalppak.or.id/

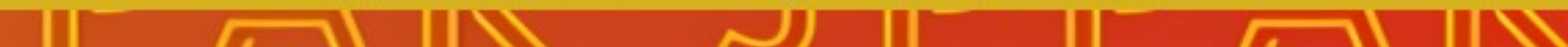




\section{Dewan Editor}

\section{JPPAK (Jurnal Penelitian Pendidikan Agama Katolik)}

\section{Pemimpin Redaksi dan Manajer Jurnal JPPAK:}

(Pst.) Ferry Hartono, S.S., Lic. S.S. (STIKAS Santo Yohanes Salib, Kalbar)

\section{Wakil-wakil Pemimpin Redaksi:}

1. Dr. Albertus Heriyanto, M.Hum. (STFT Fajar Timur Jayapura)

2. (Pst.) Fransiskus Zaverius M. Deidhae, M.A. (STP Atma Reksa Ende)

\section{Editor-editor Pelaksana:}

1. Yosua Damas Sadewo, M.Pd.

2. Silvester, M.Pd.

3. Pebria Dheni Purnasari, M.Pd.

\section{Admin OJS:}

Azriel Christian Nurcahyo, M.Kom.

\section{Editor Desain dan Tataletak:}

Yosua Damas Sadewo, M.Pd.

\section{Mitra Bebestari:}

1. (Pst.) Prof. Dr. Armada Riyanto, STFT Widya Sasana, Malang, Jatim

2. Dr. Basilius Redan Werang, S.S., S.Sos., JCL, Universitas Musamus, Merauke

3. Dr. Paskalis Edwin I Nyoman Paska, STP-IPI, Malang, Jatim

4. (Rev.) Gilbert Duuk, STL., St. Peter's College, Kuching, Sarawak, Malaysia

5. (Pst.) Dr. Carolus Patampang, S.S., M.A., Sekolah Tinggi Kateketik dan Pastoral Rantepao, Toraja, Makassar, Sulawesi Selatan.

6. (Pst.) Ignasius Samson Sudirman Refo, STPAK St. Yohanes Penginjil, Ambon, Maluku

7. Capt. Cahya Fajar Budi Hartanto, M.Mar., M.Si., Politeknik Bumi Akpelni, Semarang, Jateng.

8. Vinsensius Crispinus Lemba, S.Fil., M.Pd., Institut Keguruan dan Teknologi, Larantuka, NTT.

9. Anselmus Yata Mones, S.Fil, M.Pd., STP St. Petrus, Atambua, NTT. 
DAFTAR ISI

\section{JPPAK Volume 1 Nomor 2, September 2021}

Konstruksi Model Spiritualitas Pastoral bagi Katekis di Era Digital

Hal 125-137

Wiwin; Antonius Denny Firmanto

Efek Penggunaan Metode Pembelajaran Aktif Inovatif Kreatif Efektif

Hal 138-148

Menyenangkan terhadap Prestasi Akademik Pendidikan Agama Katolik

Kelas VIII di Sekolah Menengah Pertama Swasta Santo Xaverius 2

Kabanjahe

Erikson Simbolon; Paulinus Tibo; Rudi Hironimus Matondang

Faktor-Faktor yang Berpengaruh terhadap Pembentukan Jiwa

Hal 149-169

Kewirausahaan di Lingkungan Mahasiswa STPKat Semarang

Andarweni Astuti

Peranan Gerakan Pramuka dalam Mengembangkan Nilai-Nilai Kristiani

Hal 170-181

di My Little Island (MLI) Elementary School Malang

Intansakti Pius X

Pengenalan akan Allah dalam Pengalaman Hidup Kaum Muda Katolik

Hal 182-196

Juli Antonius Sihotang

Pastoral "Kotew" bagi Umat Paroki St. Petrus Kanisius Kandui,

Hal 197-212 Keuskupan Palangka Raya (Sebuah Telaah Teologis berdasarkan Teologi Kontekstual Stephen B. Bevans)

Eugenius Ervan Sardono; Lorensius Fura; Kristoforus Ganordin; Antonius Denny Firmanto 


\title{
JPPAK, VOLUME 01 NOMOR 02 , SEPTEMBER 2021

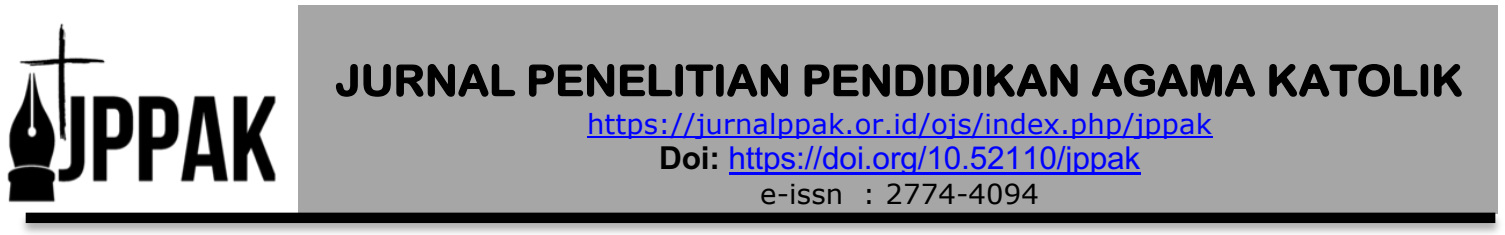

\section{Faktor-Faktor yang Berpengaruh terhadap Pembentukan Jiwa Kewirausahaan di Lingkungan Mahasiswa STPKat Semarang}

\author{
Andarweni Astuti ${ }^{1}$ \\ 1) Dosen STPKat St. Fransiskus Asisi Semarang, Jl. Ronggowarsito 8 RT 05, RW 01, \\ Semarang, Indonesia \\ Email: franosf75@gmail.com
}

ARTICLE INFO

\section{Article History}

Received 7-08-2021

Revised 20-08-2020

Accepted 12-12-2020

\section{Kata Kunci: \\ Jiwa Kewirausahaan; \\ Karakteristik Individual; \\ Psikologi; Kontekstual; Sikap Wirausahawan}

\section{A B S T R A K}

Tujuan penelitian ini yang pertama adalah untuk mengetahui faktor-faktor yang mempengaruhi jiwa kewirausahaan berdasarkan karakteristik individual, psikologi dan kontekstual. Tujuan yang kedua adalah untuk mengetahui faktor-faktor sikap dan kontekstual yang mempengaruhi mahasiswa membentuk jiwa kewirausahaanya dan tujuan penelitian ketiga adalah mengetahui ciri-ciri wirausaha yang dimiliki oleh mahasiswa STPKat Semarang. Metode penelitian yang digunakan adalah metode deskriptif yang menggambarkan fenomena yang ada saat ini di STPKat St. Fransiskus Asisi, dengan pendekatan kuantitatif dan Metode Analisis Likert. Temuan-temuan dalam penelitian ini adalah $62 \%$ faktor-faktor pembentuk jiwa kewirausahaan berasal dari karakter demografi umur dan status; $72 \%$ berasal dari sifatsifat yang dimiliki oleh seseorang; $82 \%$ berasal dari faktor kontekstual berupa adanya training kewirausahaan dan niat kuat untuk menjadi seorang guru agama Katolik dengan kepemilikan usaha sampingan. Faktor sikap dan kontekstual yang mempengaruhi dalam hal konsep diri sebesar $73 \%$ serta dalam hal minat berwirausaha sebesar $88 \%$. Ciri-ciri wirausahawan ditampakkan dalam rasa percaya diri sebesar $82 \%$; berorientasi pada hasil sebesar $83 \%$; keberanian mengambil risiko sebesar $75 \%$; kepemimpinan sebesar $83 \%$; keorisinilan $77 \%$; dan berorientasi masa depan sebesar $79 \%$. Rasa percaya diri, berorientasi pada hasil, dan kepemimpinan merupakan ciri-ciri wirausaha yang ditemukan pada sebagian besar mahasiswa STPKat Santo Fransiskus Asisi Semarang.

\section{A B S TRACT}

\section{Keywords:}

Entrepreneurial Spirit; Individual Characteristics; Psychology; Contextual; Entrepreneurial Attitude
The first purpose of this study is to determine the factors that influence the entrepreneurial spirit of individual, psychological and contextual characteristics. The second goal is to verify the attitude and contextual factors that influence students to form an entrepreneurial spirit. The third research objective is to ascertain what STPKat Semarang students own entrepreneurial 
characteristics are. The research method used is a descriptive method that describes the current phenomena in STPKat St. Fransiskus Assisi, using a quantitative approach and Likert Analysis Method. Some discoveries in this study are $62 \%$ of the factors that form the entrepreneurial spirit come from the demographic characteristics of age and status; $72 \%$ come from the traits possessed by a person; $82 \%$ come from contextual factors in the form of entrepreneurial training and a strong intention to become a Catholic teacher with business(-es) as second income. Attitude and contextual factors influence selfconcept by $73 \%$; in terms of interest in entrepreneurship by $88 \%$. Entrepreneurial traits are shown in self-confidence by $82 \%$; increasing results by $83 \%$; taking risks by $75 \%$; leadership by $83 \% ; 77 \%$ originality and $79 \%$ future-oriented. Self-confidence, focus-on-results and leadership are entrepreneurial traits found in most of STPKat Santo Fransiskus Asisi Semarang students.

\section{PENDAHULUAN}

Kewirausahaan telah diperjuangkan atau diterapkan pada banyak negara di seluruh dunia. Data dari https://thegedi.org/ menunjukkan bahwa negara-negara makmur memiliki jumlah wirausahawan sebesar 10\%. Tercatat pada tahun 2015 hingga tahun 2017 urutan negara-negara tersebut adalah Australia, Norwegia, Kanada, Luxemburg, Amerika Serikat, Israel, dan Belanda. Indonesia di tiga tahun tersebut memperoleh urutan ke 60 , ke 54 , dan ke 36 . Peringkat ini tidak bisa dikatakan baik ataupun buruk.

Pada tahun 2008, ketika terjadi krisis moneter, Indonesia mampu bertahan dari keterpurukan berkat munculnya sektor UKM. Ironisnya, hingga saat ini jumlah entrepreneur di Indonesia tetap terbatas. Pada tahun 2015 hingga 2017 niat berwirausaha (Entrepreneural Intentions) mencapai 27,47\%, 23,17\% dan 28,14\%. Ada pun nilai inovasi baru (Innovation) mencapai 17,27\%, 17,7\%, lalu menurun ke angka 11,54\%. Namun, aktivitas sebagai entrepreneur (Entrepreneurial Employee Activity) hanya $0,21 \%, 0,7 \%$ dan $1,82 \%$. Ada pun pada tahun 2015 hingga 2017, data jumlah wirausahawan secara berturut-turut adalah 3,33\%; 1,46\%; 4,86\% dibandingkan jumlah penduduk.

Dari angka-angka di atas dapat disimpulkan bahwa niat berwirausaha orang Indonesia ada, tetapi tidak sebanding dengan realisasinya. Kesenjangan ini merupakan fenomena yang perlu untuk dipecahkan. Mahasiswa sebagai generasi potensial untuk mengembangkan wirausaha perlu didampingi dengan intensif agar tidak hanya memilih menjadi job seeker melainkan menjadi job creator. Mahasiswa STPKat dibentuk dan dilatih jiwa kewirausahaannya melalui mata kuliah 
kewirausahaan. Tujuan dari mata kuliah ini adalah agar setelah lulus, selain menjadi guru agama mahasiswa juga mampu menangkap peluang untuk berwirausaha.

Pada kenyataannya, saat ini mahasiswa hanya berfokus pada tujuan untuk mendapatkan nilai yang baik saja. Menyikapi hal ini, dibutuhkan mekanisme agar terjadi peningkatan minat berwirausaha hingga mereka benar-benar memiliki usaha yang dapat dikembangkan dengan tekun. Faktor-faktor yang dapat digali untuk mencapai hal tersebut adalah faktor-faktor yang mempengaruhi minat berwirausaha berdasarkan karakteristik individual, psikologis, dan kontekstual, kemudian disertai penggalian sikap dan kontekstual yang membentuk jiwa kewirausahaan.

\section{METODE PENELITIAN}

Metode penelitan yang digunakan dalam penelitian ini adalah metode deskriptif yang menggambarkan fenomena-fenomena yang ada saat ini di STPKat Santo Fransiskus Asisi Semarang. Pendekatan penelitian adalah kuantitatif, yang memberikan peluang bagi tercapainya kesimpulan melalui interpretasi terhadap data yang diperoleh melalui kerangka pikir yang jelas.

Tahapan penelitian dimulai dari tahap perencanaan untuk mengidentifikasi masalah berupa kesenjangan antara tingginya niat kewirausahaan di Indonesia dan realisasi aktivitas berwirausahaan yang rendah. Masalah dirumuskan setelah melihat fenomena yang ada di Indonesia untuk dilakukan pendalaman lebih lanjut dan kemudian dicari pemecahan masalah. Tahap selanjutnya adalah mengadakan studi pendahuluan untuk mengumpulkan informasi berkaitan dengan masalah kesenjangan kewirausahaan di Indonesia dengan mengambil sampel penelitian para mahasiswa STPKat.

Tahap pelaksanaan penelitian dilakukan dengan mengumpulkan data dari sampel yang digunakan dan analisis dilakukan dengan menggunakan Metode Likert. Teknik pengumpulan data dilakukan dengan menyebar angket atau kuesioner yang ditujukan kepada para mahasiswa STPKat dan diperkuat dengan wawancara langsung untuk mendapatkan data secara lebih mendalam. Tahap pelaporan penelitian dilakukan setelah data terkumpul dan diolah menjadi sebuah kesimpulan. 
Analisis likert ini merupakan analisis yang mudah dan relatif sederhana untuk penghitungannya. Skor-skor yang ada bisa digunakan untuk menarik kesimpulan apakah sebuah indikator tertentu ini memiliki nilai tinggi atau rendah. Namun, dari segi kelemahannya disadari adanya keraguan apakah variabel dan indikator yang dipilih sungguh-sungguh relevan atau kurang relevan.

\section{HASIL PENELITIAN}

\section{A. Konsep Pembentukan JIwa Kewirausahaan Mahasiswa STPKat Semarang}

Analisis terhadap faktor-faktor yang mempengaruhi jiwa kewirausahaan mahasiswa berdasarkan hasil penelitian dijabarkan sebagai berikut. Hasil kuesioner tentang faktor-faktor yang mempengaruhi jiwa kewirausahaan yang di dalamnya terkandung tiga macam karakteristik pembentuk jiwa entrepreneurship manusia menurut Tantowi (2016) adalah karakteristik demografi berupa umur dan status yang mempengaruhi terbentuknya jiwa kewirausahaan. Rata-rata yang didapatkan sebesar $62 \%$ yang diartikan bahwa karakteristik demografi secara keseluruhan membawa dampak yang cukup untuk membentuk jiwa kewirausahaan. Pertanyaan yang menghasilkan nilai baik antara 68\%-90\% adalah pertanyaan tentang apakah sewaktu kecil para mahasiswa memiliki saudara seorang entrepreneur. Hasilnya menunjukkan bahwa $76 \%$ menjawab mereka memiliki saudara seorang wirausahawan. Selanjutnya untuk pertanyaan kapan entrepreneurship mulai dikenal, menunjukkan bahwa sebanyak $74 \%$ responden menjawab sesudah SMA. Pertanyaan berikutnya tentang bidang usaha yang dilakukan orang tua menunjukkan data sebesar $74 \%$ menjawab pengusaha peternakan, $71 \%$ menjawab pengusaha pertanian, $76 \%$ menjawab pengusaha makanan dan minuman. Munculnya nilai tersebut menandakan bahwa sebagian besar atau lebih dari 50\% mahasiswa dipengaruhi oleh pengalaman wirausaha saudaranya ketika mereka kecil sampai sekolah menengah atas. Untuk tahap usia atau pendidikan selanjutnya tidak tampak bahwa mereka dipengaruhi.

Karakteristik kedua adalah karakteristik psikologis, yang berisi pertanyaan mengenai sifat-sifat yang dimiliki oleh para mahasiswa. Sifat-sifat tersebut antara lain dominating controller, cautious analyzer, supportive relaters, serta fun-loving promoters. Berdasarkan hasil perhitungan maka diperoleh nilai rata-rata sebesar $72 \%$. Nilai ini mempunyai arti bahwa rata-rata mahasiswa mendukung jiwa kewirausahaan, dengan nilai maksimal sebesar $85 \%$ (kategori sangat baik) pada 
sifat supportive relaters. Sifat supportive relaters diartikan sebagai sifat yang suka mendukung teman yang sukses, menjadi teman yang setia, ceria, namun jarang mengusulkan ide atau bertanya. Nilai minimum terdapat pada sifat cautious analyzer yaitu sikap yang lebih sering bertanya daripada membuat penyataanpernyataan, yakni sebesar 63\% (kategori cukup). Sifat seorang wirausahawan yang baik harus mampu masuk ke dalam sifat sesorang. Sebaliknya, seorang wirausahawan yang memiliki sifat demikian harus mampu menyesuaikan diri dengan lingkungan yang dihadapi. Jika sifat yang dimiliki tidak mendukung jiwa seorang entrepreneur, ia harus mampu memperbaiki diri.

Pertanyaan tentang kepemimpinan, keberanian menanggung risiko, kapasitas, dan penilaian diri mendapatkan rata-rata $82 \%$ (baik). Nilai minimum $66 \%$ ada pada pernyataan bahwa mahasiswa lebih suka jadi pemimpin. Ada pun pernyataan dengan nilai maksimum sebesar $87 \%$ ada pada pernyataan bahwa anda akan memotivasi diri anda sendiri ketika anda jatuh, untuk bangkit kembali.

Karakteristik ketiga adalah faktor kontekstual, faktor ini mendapatkan nilai rata-rata $82 \%$ (baik). Nilai minimum sebesar $47 \%$ terletak pada pernyataan bahwa mahasiswa sudah memiliki usaha saat ini. Nilai maksimum sebesar $94 \%$ terdapat pada penyataan ada keinginan kuat menjadi guru agama yang juga memiliki usaha sampingan. Dari karakteristik kontekstual ini dapat disimpulkan bahwa mahasiswa menghendaki pelatihan dan training kewirausahaan lebih banyak lagi.

\section{B. Faktor Sikap dan Kontekstual Mahasiswa STPKat Semarang}

Faktor-faktor sikap dan konteksual yang mempengaruhi pembentukkan jiwa kewirausahaan mahasiswa di saat kuliah dijabarkan sebagai berikut:

\section{Konsep Diri}

Faktor-faktor sikap dan kontesktual yang mempengaruhi mahasiswa membentuk jiwa kewirausahaanya dapat dilihat dari segi konsep diri; dalam hal ini tercermin pada sikap mampu mengatasi masalah. Skor rata-rata yang diperoleh pada aspek ini adalah $73 \%$, dengan nilai maksimum sebesar $80 \%$. Nilai maksimum tersebut terdapat pada aspek pernyataan tentang perhatian terhadap hal-hal detail dan usaha pemecahannya. Sedangkan nilai minimum yang diperoleh adalah $67 \%$. Nilai ini didapat dalam pernyataan "saya dapat mengatasi masalah secara efektif". Berdasarkan hasil tersebut, maka dapat disimpulkan bahwa dalam pernyataan tentang "perasaan mampu mengatasi masalah", mahasiswa STPKat lebih 
cenderung mempelajari masalah secara detail dan mencari informasi pemecahannya daripada mengatasi masalah secara efektif.

Konsep diri selanjutnya adalah merasa setara dengan orang lain. Pernyataan ini mendapat nilai rata-rata $84 \%$. Nilai minimum $79 \%$ didapat dalam pernyataan dalam bergaul saya bersikap rendah hati. Ada pun nilai maksimum sebesar $93 \%$ didapat dalam pernyataan "tidak menyukai pembedaan-pembedaan terkait status orang lain”. Berdasarkan nilai-nilai minimum dan maksimum tersebut dapat didefinisikan bahwa mahasiswa STPKat merasa setara dengan yang lain dalam arti mereka siap menghadapi perbedaan status sosial. Kondisi demikian dapat menunjukkan bahwa mahasiswa mementingkan kebersamaan lebih daripada kepentingan pribadi.

Hasil analisis pada konsep diri yang ketiga menunjukkan nilai rata-rata sebesar $88 \%$. Skor ini menunjukkan bahwa mahasiswa STPKat berani menerima pujian tanpa malu. Nilai maksimum 93\% terdapat pada pernyataan "menganggap pujian sebagai dasar untuk melakukan hal yang lebih besar agar mencapai prestasi yang maksimal", sedangkan nilai minimum sebesar $83 \%$ terdapat pada pernyataan "saya tetap rendah hati setelah menerima pujian". Berdasarkan nilai maksimum dan minimum ini bisa disimpulkan bahwa mahasiswa STPKat berani mengambil sikap bukan saja menerima segala pujian dengan tetap rendah hati, tetapi mereka juga mau menjadikan pujian tersebut sebagai acuan berprestasi.

Konsep diri keempat mendapatkan nilai rata-rata 90\%. Nilai ini menunjukkan bahwa para mahasiswa STPKat mampu memperbaiki diri dari kesalahan dengan baik. Nilai minimum sebesar $87 \%$ terdapat pada pernyataan "saya mau menerima kritikan orang lain". Nilai maksimum sebesar 92\% terdapat pada pernyataan soal dilakukannya instrospeksi diri dalam setiap kegagalan agar menjadi sebuah pembelajaran yang berharga. Berdasarkan perolehan nilai maksimum dan minimum tersebut dapat disimpulkan bahwa mereka saja mampu menerima kritikan orang lain, tetapi juga mau melakukan instrospeksi diri dan belajar dari kegagalan.

Kesimpulan konsep diri mahasiswa STPKat saat ini adalah mereka mampu untuk memperbaiki diri dengan melakukan introspeksi diri, belajar dari kegagalan, mampu mengolah pujian tanpa rasa malu, menganggap atau mengolah pujian yang diterima sebagai pedoman untuk lebih meningkatakan diri dalam meraih prestasi, serta tidak membeda-bedaan status sosial dalam pergaulan. 


\section{Minat Berwirausaha}

Minat berwirausaha ini digali melalui pernyataan tentang prestise sosial, tantangan pribadi, menjadi bos, inovasi, kepemimpinan, fleksibilitas, dan keuntungan. Dalam hal prestise sosial diperoleh nilai rata-rata sebesar $88 \%$. Nilai rata-rata tersebut didapatkan dari nilai maksimum sebesar $93 \%$ dan nilai minimum sebesar $83 \%$. Berdasarkan nilai-nilai tersebut dapat diambil kesimpulan bahwa mereka akan merasa bangga bila memiliki bisnis sendiri baik bisnis yang baru dibuka atau bisnis yang sudah berjalan (baik bisnis yang merugi ataupun bisnis yang menguntungkan), bukan sekedar bisnis yang dilakukan agar bisa dibanggakan karena menghasilkan untung.

Dalam hal menyikapi tantangan pribadi diperoleh nilai rata-rata sebesar $87 \%$. Ini berarti mereka mampu menyikapi tantangan pribadi tersebut, dengan nilai minimum sebesar $85 \%$ dan nilai maksimum sebesar $92 \%$. Berdasarkan nilai maksimum dan nilai minimum ini dapat disimpulkan bahwa mereka ingin selalu mencoba hal-hal baru dan siap menghadapi risiko atas keputusan yang mereka ambil, terlebih lagi mereka memegang prinsip kalau orang lain bisa mereka pun harus bisa.

Minat berwirausaha terlihat juga melalui bagaimana sikap mereka jika menjadi bos, rata-rata yang didapatkan adalah sebesar $71 \%$. Rata-rata ini lebih kecil jika dibandingkan pernyataan-pernyataan sebelumnya. Kesan pertama yang didapatkan adalah mereka belum percaya diri untuk menjadi bos. Nilai maksimum didapatkan sebesar $83 \%$ dalam pernyataan "saya ingin punya wewenang bertanggungjawab atas pencapaian hasil", sedangkan nilai minimum sebesar $62 \%$ didapatkan dalam pernyataan "saya lebih senang mengambil keputusan sendiri". Berdasarkan nilai maksimum dan nilai minimum tersebut bisa disimpulkan bahwa ada keinginan dan cita-cita dalam diri mereka untuk punya wewenang bertanggung jawab atas pencapaian hasil, tidak ingin mengambil keputusan sendiri, serta masih belum berani lepas dari kendali orang lain.

Bagaimana minat berwirausaha mereka jika dilihat dari inovasi? Nilai ratarata yang dihasilkan sebesar $79 \%$ masuk dalam golongan baik. Berdasarkan penilaian maksimum dan minimumnya dihasilkan nilai $84 \%$ dan $71 \%$, yang dapat disimpulkan sebagai berikut: mereka memiliki keinginan untuk menciptakan atau mengembangkan sesuatu yang kreatif, namun masih perlu ditambah pengetahuan yang lebih banyak lagi mengenai cara-cara menemukan ide-ide baru. 
Segi kepemimpinan mendapat rata-rata sebesar $74 \%$. Ini masih masuk dalam kategori baik. Pernyataan "saya mempunyai kemampuan untuk mempengaruhi orang lain" mendapat nilai minimum yaitu $67 \%$. Selanjutnya, dalam hal berinteraksi dengan orang lain berdasarkan berbagai kepribadian masingmasing, diperoleh nilai tertinggi sebesar $80 \%$, ditambah lagi dengan dimilikinya kemauan untuk mengambil inisiatif terlebih dahulu.

Segi fleksibilitas dalam menggali minat berwirausaha mendapatkan nilai rata-rata yang tidak begitu tinggi, yaitu sebesar $69 \%$. Meskipun masih dalam kategori penilaian baik, nilai minimum dan nilai maksimumnya relatif lebih kecil dari pernyataan sebelumnya yaitu sebesar $59 \%$ dan $76 \%$. Nilai minimum menggambarkan bahwa mereka menyukai rutinitas. Ada pun nilai maksimumnya terletak dalam pernyataan mereka ingin bebas mengatur usaha mereka sendiri. Dari sini bisa disimpulkan bahwa mahasiswa STPKat ingin bebas mengatur usaha sendiri dalam kerangka keteraturan hidup atau rutinitas yang teratur.

Dalam sikap terhadap keuntungan diperoleh nilai rata-rata $88 \%$. Keuntungan dalam berwirausaha menjadi salah satu faktor atau tujuan utama. Hal ini disadari oleh mahasiswa STPKat. Sikap tersebut selaras dengan pilihan penyataan bahwa mereka ingin merasakan keuntungan usaha milik sendiri dengan nilai $92 \%$. Sementara nilai yang tidak beda jauh dari nilai maksimum tersebut dianggap sebagai nilai minimum yaitu sebesar $84 \%$ pada pernyataan "keinginan untuk menjadi kaya karena usaha dan kerja keras dirinya sendiri". Pada intinya minat mahasiswa akan keuntungan berada pada kategori yang relatif tinggi.

Dari uraian soal minat berwirausaha mahasiswa STPKat di atas dapat disimpulkan bahwa saat ini mereka dipengaruhi oleh faktor prestise sosial, keuntungan, dan tantangan pribadi. Prestise sosial diartikan sebagai adanya sebuah kebanggaan yang akan muncul dengan memiliki usaha bisnis sendiri. Minta berwirausaha mereka juga masih didorong oleh minat akan keuntungan yang akan diraih. Selain itu, minat berwirausaha mahasiswa STPKat juga ditentukan oleh faktor tantangan pribadi: jika orang lain bisa maka mereka juga harus bisa.

\section{Ciri-ciri Wirausahawan}

Penggalian faktor-faktor sikap dan kontekstual yang mempengaruhi mahasiswa dalam pembentukkan jiwa kewirausahaannya dapat diklasifikasikan 
menjadi ciri-ciri wirausaha. Ciri-ciri wirausahawan tersebut antara lain: percaya diri, beorientasi pada tugas dan hasil, keberanian mengambil risiko, kepemimpinan, keorisinilan, serta berorientasi pada masa depan.

Ciri-ciri wirausahawan yang pertama adalah kepercayaan diri. Dalam pengisian kuesioner kepada mahasiswa, sikap percaya diri mendapat nilai ratarata $82 \%$, dengan nilai minimum sebesar $77 \%$ yang tergambar pada pernyataan "saya memilih sikap optimis". Nilai maksimum terdapat pada pernyataan rasa bangga dan berharga akan dirinya sendiri dengan perolehan nilai sebesar $89 \%$. Nilai-nilai tersebut berada dalam kategori baik. Dapat disimpulkan bahwa sikap percaya diri telah dimiliki oleh para mahasiswa STPKat.

Ciri kedua seorang wirausahawan adalah berorientasi pada tugas dan hasil. Dalam kuesioner yang disebarkan, pernyataan ini mendapat nilai rata-rata sebesar $83 \%$, yang didukung oleh pernyataan "saya mempunyai keinginan untuk mendapatkan laba" (nilai maksimum sebesar $85 \%$ ). Ciri kedua, ketekunan untuk mencapai suatu tujuan, mendapat nilai lebih dari $80 \%$.

Ciri ketiga seorang wirausahawan adalah keberanian mengambil risiko. Nilai rata-rata yang diperoleh dalam kuesioner tentang keberanian mengambil risiko ini adalah $75 \%$. Nilai rata-rata ini masih relatif lebih kecil daripada nilai sebelumnya. Sikap ini menjadi salah satu kunci sukses menjadi seorang wirausahawan. Jika tidak mampu mengelola risiko, usaha akan cepat gulung tikar. Kesadaran untuk siap menerima risiko belum begitu tampak. Terbukti dengan nilai maksimum yang didapat sebesar $75 \%$, dan nilai maksimum juga $75 \%$. Pengambilan risiko ini meliputi kemampuan berspekulasi, kemampuan untuk menanggung resiko, serta kemampuan untuk menyukai risiko, tetapi realistis dalam mengejar tujuan.

Ciri keeempat untuk menjadi seorang wirausahawan adalah kepemimpinan; memimpin orang lain dalam sebuah pekerjaan. Hasil rata-rata yang didapatkan adalah sebesar $83 \%$. Hasil ini berarti bahwa kepemimpinan disadari oleh para mahasiswa STPKat sebagai sesuatu yang penting dalam berwirausaha. Nilai maksimum terdapat pada pernyataan kesediaan menerima kritik dari orang lain yaitu sebesar $86 \%$. Nilai minimum terdapat dalam pernyataan "saya dapat bekerjasama dengan orang lain" dengan nilai $79 \%$.

Ciri seorang wirausahawan yang kelima adalah orisinalitas. Ciri ini mendapatkan nilai rata-rata sebesar $76 \%$. Ada pun, nilai maksimum dan nilai minimumnya berturut-turut $77 \%$ dan $72 \%$. Pada ciri ini, mahasiswa masih berada 
pada tahap "kepemilikan imajinasi yang tinggi". Untuk "berpikir keluar dari yang biasanya" masih menjadi pilihan minimum para mahasiswa.

Ciri terakhir dari seorang wirausahawan adalah berorientasi pada masa depan. Rata-rata yang didapatkan dari ciri ini adalah 79\%. Nilai maksimum dan nilai minimumnya sebesar $82 \%$ dan $75 \%$. Nilai ini menunjukkan bahwa di satu sisi mahasiswa STPKat memiliki upaya untuk mengembangkan dan mengevaluasi diri demi mencapai tujuan. Namun, di sisi lain, mereka juga memiliki sifat tidak cepat puas atas hasil yang telah mereka peroleh. Untuk ini mereka perlu membuat skala prioritas yang jelas.

Dari hasil kuesioner mengenai ciri-ciri wirausahawan dapat disimpulkan bahwa mahasiswa STPKat menaruh perhatian pada beberapa hal, sebagai berikut:

(1) dari aspek kepemimpinan: kemampuan untuk melakukan kerjasama, keterbukaan untuk dikritik oleh sesama demi kemajuan, serta motivasi untuk mencapai hasil.

(2) berorientasi pada hasil atau laba. Untuk ini mereka sadar perlu tekad untuk bekerja keras dan tekun.

(3) kepercayaan diri, mereka menaruh perhatian pada pentingnya perasaan berharga dan bangga terhadap diri sendiri, sikap optimis, serta memahami kekuatan dan kelemahan diri sendiri.

\section{DISKUSI}

Faktor-faktor yang mempengaruhi kecenderungan seseorang untuk melakukan wirausaha adalah sebagai berikut: (1) karakteristik individual, (2) karakteristik psikologis, dan (3) faktor kontekstual. Karakteristik individual sendiri terdiri dari beberapa faktor yaitu jenis kelamin, umur, dan status. Karakteristik psikologis terdiri dari beberapa faktor pembentuk, yaitu kreativitas, kepemimpinan, resiko yang diterima, dan kapasitas dan penilaian diri. Sedangkan faktor kontekstual terdiri dari segala faktor yang berhubungan dengan profesi, pelatihan dan pengembangan kewirausahaan, dan pelatihan akademik secara umum. Konsep pembentukan jiwa entrepreneurship yang ditinjau dari karakteristik individual, karakteristik psikologis, dan faktor kontestual digambarkan sebagai berikut: 


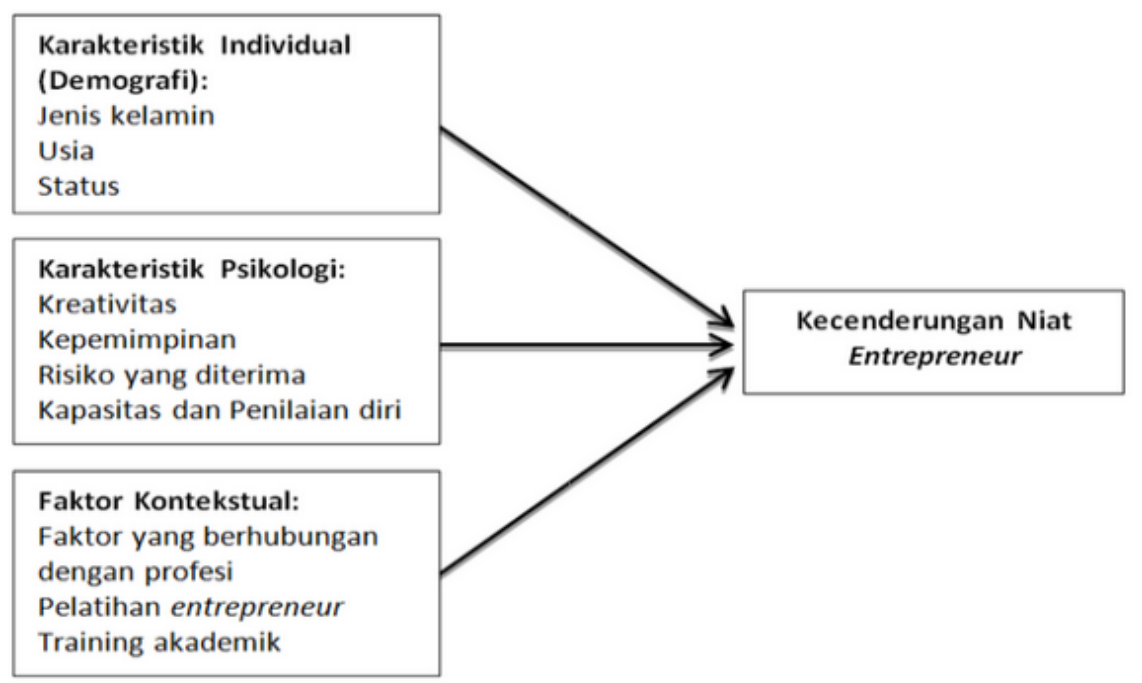

(Tontowi, 2016)

Faktor-faktor pembentuk jiwa kewirausahaan tersebut diuraikan berikut ini: seseorang terpengaruh untuk menjadi entrepreneur sebagai pilihan hidupnya (Tontowi, 2016) disebabkan oleh beberapa hal berikut ini (1) faktor personal/individual merupakan faktor yang melihat pengalaman hidup seseorang yang berasal dari lingkungan ataupun keluarganya mulai dari kecil sampai dewasa yang mempengaruhi jiwa entrepreneur; (2) keinginan menjadi pengusaha tersebut semakin diperkuat lagi atau dipacu pada saat seseorang beranjak dewasa, ia bergaul dengan sahabat, teman-teman kuliah yang menekuni dunia bisnis; (3) kesuksesan saudara, teman, sahabat sebagai pengusaha mendorong keinginan seseorang untuk memilki cita-cita untuk menjadi seorang wirausahawan/entrepreneur yang sukses; (4) stimulus lain yang mampu memicu keinginan menjadi seorang pengusaha adalah ketidaknyamanan suasana kerja atau lingkungan kerja tempat dia beraktivitas. Orang akan merespon keadaan demikian, dengan mencari suasana kerja yang lain, yang tidak terikat dengan sebuah perusahaan; (5) pendidikan seseorang juga mempengaruhi keinginan seseorang untuk menjadi seorang pengusaha. Rata-rata tingkat pendidikan yang semakin tinggi tidak begitu berpengaruh terhadap niat seseorang untuk menjadi pengusaha, mereka yang tingkat pendidikannya tidak telalu tinggi, memiliki stimulus lebih besar untuk menjadi seorang pengusaha; (6) tipe kepribadian seseorang atau personality juga memberi dorongan terhadap niat berwirausaha. Tipe-tipe kepribadian seseorang seperti analytic, advocator, controller, serta fasilitator memiliki jenis minat tersendiri untuk pemilihan jalan hidup sebagai pengusaha 


\section{A. Kelompok Orang yang Memiliki Konsep Diri Positif}

Seseorang yang memiliki konsep diri yang positif, ditandai dengan lima hal, yaitu: (1) yakin akan kemampuannya terutama dalam mengatasi masalahmasalah dirinya; (2) adanya perasaan setara dengan orang lain sehingga dia selalu percaya diri dan selalu siap untuk beradaptasi dengan orang lain; (3) bersedia menerima pujian tanpa rasa malu; (4) menyadari, setiap orang mempunyai berbagai perasaan, keinginan, dan perilaku yang berbeda-beda sehingga perawakan, pikiran, perilakunya tidak seluruhnya akan disetujui orang lain (masyarakat); dan (5) mampu memperbaiki dirinya sehingga dia bersedia mengungkapkan aspek-aspek kepribadian yang tidak disenanginya dan berupaya untuk mengubahnya ke arah yang lebih baik (Lydianingtyas et al., 2018).

Karakteristik orang yang memiliki konsep diri positif bisa dijabarkan dalam 11 hal sebagai berikut:

(1) meyakini nilai-nilai atau prinsip-prinsip tertentu dan bersedia mempertahankannya, meskipun harus menghadapi berbagai pendapat kelompok yang kuat, dan merasa cukup mampu mengubah prinsip-prinsip tersebut bila bukti-bukti atau pengalaman baru menunjukan hal itu salah;

(2) mampu bertindak dengan baik sesuai dengan penilaian baik yang diberikan orang terhadapnya, tanpa adanya rasa bersalah yang tak wajar ketika orang lain merasa tidak setuju dengan apa yang telah dilakukan olehnya;

(3) seseorang yang tidak terlalu cemas dengan apa yang akan terjadi di masa lampau masa depan maupun saat sekarang ini;

(4) percaya diri dan yakin akan kamampuan diri untuk mengatasi resiko yang muncul dari tindakannya meskipun usahanya gagal;

(5) sikap yakin akan kesetaraannya dengan orang lain dan adanya kesadaran bahwa orang lain memiliki kelebihan dan kekurangannya, sehingga tidak merasa lebih dari orang lain;

(6) sanggup menerima dirinya sebagai orang penting dan bernilai bagi orang lain;

(7) dapat menerima pujian tanpa berpura-pura rendah hati atau menerima penghargaan tanpa merasa bersalah;

(8) mengakui bahwa dia memiliki dorongan atau keinginan, dari perasaan marah sampai cinta, dari perasaan sedih menjadi perasaan bahagia atau dari perasaan kecewa hingga kepuasan yang mendalam;

(9) cenderung menolak usaha orang lain untuk mendominasinya; 
(10) memiliki prinsip, bisa mengatur waktu, mampu mengatasi persoalan, percaya diri, mandiri, peka akan kebutuhan dirinya dan orang lain, bisa berempati, mampu bersoalisasi dengan orang lain, bisa menikmati dirinya secara utuh dalam berbagai kegiatan, pekerjaan, permainan, persahabatan atau sekedar mengisi waktu, peka pada kebutuhan sosial dan kebiasaan sosial yang telah diterima, terutama sekali pada gagasan bahwa dia tidak akan bisa bersenang-bersenang dengan mengorbankan orang lain.

(11) mau terbuka, sikap mau terbuka terhadap sesama, dan terbuka terhadap apa saja yang membangun. Konsep diri yang tidak dibuat-buat atau meniru orang lain akan mempermudah diri untuk menerima masukan atau terbuka terhadap pengalaman baru, tidak memiliki sikap defensif yang berlebihan, percaya pada diri sendiri, menghargai dan percaya pada orang lain, positive thinking pada diri sendiri dan orang lain, terbuka dan peka terhadap perubahan, berani menghadapi resiko, dan mampu mencari serta memilih solusi yang baik dari permasalahan yang muncul.

Seseorang dikatakan memiliki minat wirausaha jika mereka selalu berusaha bangkit dari kegagalan, kepercayaan pada kemampuan diri sendiri. Ciri lainnya adalah adanya locus of control dan self detemination: mampu dalam pengelolaan risiko yang muncul, mampu memandang adanya perubahan sebagai suatu tantangan baru, memiliki sikap toleran walaupun ada banyak pilihan, seorang yang perfect, selalu berinisiatif, berpandangan luas, kreatif, berpedoman bahwa setiap waktu yang ada merupakan sebuah peluang untuk maju, memiliki kehendak yang kuat, serta memiliki motivasi yang tinggi, mengelola resiko, perubahan dipandang sebagai kesempatan, dan toleran terhadap banyaknya pilihan (Pieter, 2017). 
Tabel 1. Tabel Daftar Ciri-ciri, Jiwa, dan Sikap Wirausaha

\begin{tabular}{l|l}
\hline Ciri-ciri & Jiwa Dan Sikap Kewirausahaan \\
\hline Sikap percaya diri & Yakin, selalu optimistis; \\
\hline \multirow{2}{*}{$\begin{array}{l}\text { Orang yang tidak tergantung dari persepsi } \\
\text { orang lain, focus dalam mengejar } \\
\text { keuntungan/laba, tekun, tabah bekerja, pantang } \\
\text { menyerah, selalu memiliki motivasi, memiliki } \\
\text { inisiatif, selalu bergairah dalam bekerja; }\end{array}$} \\
\cline { 2 - 2 } $\begin{array}{l}\text { Orang yang mampu take and manage the risks, } \\
\text { mampu berjuang untuk mengatasi setiap } \\
\text { peluang dan tantangan. }\end{array}$ \\
\hline Orisinal & $\begin{array}{l}\text { Seorang leader yang baik, mampu berteman } \\
\text { dan beradaptasi dengan siapa saja, terbuka } \\
\text { terhadap perubahan, berani menerima kritik } \\
\text { dan usulan perbaikan dari orang lain. }\end{array}$ \\
\hline Future Orientation & $\begin{array}{l}\text { Orang yang terus berinovatif, memiliki banyak } \\
\text { sources, selalu bisa dan memiliki kemampuan } \\
\text { untuk mencari pengetahuan baru. }\end{array}$ \\
\hline & $\begin{array}{l}\text { Orang yang berpandangan jauh dan tepat } \\
\text { sasaran. }\end{array}$ \\
\hline
\end{tabular}

\section{Karakteristik Wirausahawan dan Nilai-nilainya yang Hakiki}

Seorang wirausahawan dikatakan berhasil apabila memiliki karakteristik yang diungkapkan oleh M. Scarborough dan Thomas W. Zimmerer, dalam buku berjudul Entrepreneur and Small Enterprise Development Report, yang berbunyi sebagai berikut: “... bersikap proaktif, memiliki inisiatif dan ketegasan (assertive), selalu orientasi pada keberhasilan terlihat dalam kemampuan dalam melihat dan berekasi terhadap peluang yang ada, bagaimana mengefisiensi dan mengekfektifkan sumber daya, berorientasi pada hasil yang berkualitas, memiliki rencana, mengadakan monitoring kegiatan usaha, bekerjasama dengan orang lain dengan penuh tanggung jawab, mampu mengelola kerjasama dengan rekan bisnis dengan baik." (Scarborough \& Zimmerer, 1998). Kepribadian seseorang sangat mempengaruhi keberhasilan atau gagalnya sebuah usaha seperti diungkapkan oleh The Officer of Advocacy of Small Business Administration (1989) yang dikutip oleh Dab Steinhoff dan John F Burges (1993:37; cfr. Widaningsih \& Ariyanti, 2018).

Kecenderungan profil pribadi wirausahawan dapat dilihat dari kegiatan sehari-hari yang dilakukan antara lain: seorang wirausahawan adalah seseorang yang tidak menyukai adanya keteraturan acara, kebiasaaan, dan segala hal yang bersifat tetap. la memiliki kecenderungan mudah bosan dengan rutinitas yang kemudian memunculkan adanya harapan untuk sebuah perubahan, tambahan, terjadi perbaikan, menjadi semakin kaya dalam ide, perbaikan mutu. la memiliki keberanian. Seorang wirausahawan ingin selalu menunjukkan sikap mandiri 
dalam menemukan atau memunculkan ide-ide baru atau imajinasi baru berdasarkan prakarsa dirinya. Dia juga adalah orang yang selalu berinovasi dan menghasilkan karya yang bisa ditunjukkan kepada orang lain. Dia berusaha agar gagasan barunya diterima dan bisa dikembangkan, dan bertanggungjawab dalam pengelolaan hingga gagasannya tersebut bisa mencapai final yang disetujui oleh banyak orang. Dalam rangka perbaikan, ia terbuka menerima perubahan dan modifikasi dari usahanya yang berasal dari orang lain. Dia juga mampu bekerjasama dengan pihak lain dengan hati-hati dan cermat. Dia memiliki kesiapan untuk bersaing dengan usaha atau ide orang lain. Gangguan, hambatan, rintangan, dan risiko justru dilihatnya sebagai peluang baru untuk mengembangkan usaha.

\section{Sikap dan Kepribadian Kewirausahaan}

Sikap dan kepribadian kewirausahaan akan dilihat melalui kualitas dan sikap orang masa kini, atau orang modern. Manusia yang berpartisipasi dalam produksi modern yang berkualitas terlihat atau tercermin pada mereka yang menerapkan sikap, nilai, dan tingkah laku kehidupan sosial secara modern. Ciricirinya, antara lain, adanya sikap terbuka bagi pembaharuan pengalaman, peka terhadap adanya perubahan sosial, memiliki sikap yang realistis tidak dibuat-buat terhadap kenyataan dan pendapat yang ada, memandang ke depan dan berjuang di masa kini, tidak berpegangan pada pengalaman masa lampau, memiliki perencanaan, penuh kepercayaan diri, adanya aspirasi, memiliki jenjang pendidikan dan keahlian yang sesuai, memliliki sikap respect terhadap perubahan, kehati-hatian, dan memahami tentang proses produksi (Anwar, 2014).

Peluang-peluang, tantangan dan perubahan-perubahan sosial yang ada akan mudah ditangkap oleh mereka yang siap terbuka terhadap pengalaman baru, mereka juga siap untuk selalu memperbaharui standar hidupnya menjadi lebih baik lagi. Sikap keterbukaan terhadap peluang atau ide baru ini menjadi ciri jiwa wirausahawan yang kreatif dan inovatif. Latar belakang pendidikan, pengalaman pengalaman yang banyak baik pengalaman lama atau pengalaman baru menjadikan seorang wirausahawan memiliki pandangan yang semakin luas dan dinamis, selalu terbuka terhadap pembaharuan, hal tersebut akan mempengaruhi pula percepatan perkembangan lapangan industri yang ditangani. Seorang wirausahawan seharusnya mampu memadukan antara kemampuan diri yang peka terhadap perubahan dan keberanian memulai usaha, tidak mudah patah 
semangat, mampu berusaha secara sistematis dan rasional. Seorang wisuda juga hendaknya memiliki sumbangan dan karya untuk majunya kemanusiaan berdasarkan hal yang benar dan baik. Wirausaha yang mampu memberikan sumbangan dan karya tersebut merupakan seseorang yang berkepribadian dan berbudi luhur dan unggul, yang siap untuk mejadi teladan bagi orang lain.

Wirausahawan adalah seorang motivator dan inovator, yang memiliki kemampuan secara naluriah untuk mengelola harta benda sedemikian rupa agar mempunyai manfaat lebih dari keadaan sebelumnya. la juga memiliki semangat untuk selalu berubah sesuai dengan peluang yang tersedia. la harus mampu bersaing serta tetap mampu bertahan menghadapi tantangan. Seorang pengusaha harus mampu menemukan kombinasi gabungan dari kelima proses inovasi yaitu pengenalan barang, menemukan pasar, menerapkan metode produksi, memiliki sumber-sumber bahan mentah, memiliki organisasi industri yang baru. Definisi seorang wirausahawan yang bisa diambil, seorang wirausahawan adalah dia yang dengan seluruh daya kemampuannya berupaya menghasilkan penemuan hal-hal baru untuk mendukung tujuan perusahaannya dalam mencapai keuntungan maksimal.

Wirausahawan adalah dia yang mesti memiliki inisiatif dan organisator utama dalam perusahaannya. Pola tingkah laku seorang yang memiliki jiwa wirausaha antara lain adalah (1) memiliki inovasi, dalam hal ini diartikan sebagai seseorang yang mampu menjadi pencipta, penemu dan penerima ide-ide, seorang yang berani take and manage the risk; (2) memiliki keberanian menimbang dan penerimaan terhadap resiko agar menjadi salah satu pertimbangan dalam pengambilan keputusan serta dalam usaha mengatasi pada saat perusahaan menghadapi kesulitan; (3) memiliki kemampuan manajerial, yang diartikan sebagai kemampuan wirausaha untuk pelaksanaan fungsi-fungsi manajemen, meliputi planning, organizing, actuating, controlling terhadap jalannya usaha; (4) leadership yang merupakan usaha untuk memberikan motivasi, melaksanakan, dan memberikan pengarahan agar usaha berjalan pada tujuan yang ditetapkan (Anwar, 2014).

Wirausahawan adalah seorang inovator yang harus mengkombinasikan sumber-sumber, teknologi, pangsa pasar, serta metode-metode produksi yang baru. Perilaku inovatif dan kreatif tersebut merupakan "entrepreneurial action", dengan ciri-ciri yang melekat padanya, antara lain: memiliki kemampuan mengelola risiko agar investasi berjalan dengan aman; memiliki jiwa kemandirian, 
memiliki jiwa kreatifitas untuk mencari peluang agar mampu menciptakan keuntungan baru; serta mampu memperhitungkan perkembangan masa depan (Handini \& Sukesi, 2019).

Nilai-nilai pribadi wirausahawan dipengaruhi oleh keberaniannya menghadapi risiko, positive thinking, sikap optimistis, kemandirian, serta niatnya untuk terus belajar. Sebaliknya, faktor-faktor yang dapat menggagalkan wirausahawan terdiri dari faktor-faktor eksternal dan internal. Faktor-faktor internal tersebut, antara lain meliputi: kemauan dan kemampuan personal yang lemah. Faktor-faktor eksternal mencakup kekurangan peluang dan kesempatan (Dinar \& Ahmad, 2020).

\section{E. Motivasi Berprestasi Kewirausahaan}

Maslow mengajukan teori hierarki kebutuhan sebagai dasar motivasi seseorang. Maslow mengatakan bahwa ada tingkatan kebutuhan pada seseorang sekaligus tingkatan pemuasannya. Jika diurutkan dari atas ke bawah, kebutuhankebutuhan tersebut mencakup: kebutuhan aktualisasi diri, kebutuhan harga diri, kebutuhan sosial, kebutuhan akan keamanan, dan yang paling rendah adalah kebutuhan fisik (Widaningsih \& Ariyanti, 2018). Berdasarkan teori Maslow tersebut, minat berwirausaha seseorang dipengaruhi oleh adanya motivasi untuk mendapatkan prestasi (achievement motive). Motivasi prestasi menampilkan hasrat seseorang untuk mencapai hal-hal paling baik untuk mendapatkan kepuasan pribadi. Hal-hal tersebut biasanya dipicu oleh kebutuhan-kebutuhan lain yang harus terpenuhi.

Motivasi untuk mengejar prestasi tersebut memiliki fungsi antara lain: (1) menjadi daya dorong manusia untuk menjadi motor penggerak yang melepaskan energi yang ada; (2) penentu arah bagi perbuatan untuk menuju ke tujuan yang ditetapkan; (3) menjadi penyeleksi perbuatan, untuk menentukan perbuatan mana yang akan dilakukan untuk sampai pada tujuan perusahaan, agar perbuatan yang dilakukan berjalan efektif dan efisien, serta tidak salah langkah (Widaningsih \& Ariyanti, 2018).

Indikator pertanyaan untuk mengetahui faktor yang mempengaruhi jiwa kewirausahaan ini antara lain ditunjukkan oleh tabel di bawah ini: 
Tabel 2. Faktor Penentu Jiwa Kewirausahaan berdasarkan Konsep Pembentukannya

\begin{tabular}{|c|c|c|}
\hline \multirow[t]{2}{*}{ No } & \multicolumn{2}{|l|}{ Variabel } \\
\hline & Konsep Pembentukan Jiwa Kewirausahaan & $\begin{array}{l}\text { Faktor Sikap dan } \\
\text { Kontekstual }\end{array}$ \\
\hline 1 & $\begin{array}{l}\text { Karakteristik demografi: Memiliki saudara } \\
\text { wirausahawan. Pertama kali mengenal wirausaha. } \\
\text { Keluarga mendukung untuk menjadi wirausaha. Jika } \\
\text { keadaan situasi kerja tidak mendukung sikap } \\
\text { wirausaha. Setelah lulus akan berwirausaha. }\end{array}$ & $\begin{array}{l}\text { Konsep diri: mampu } \\
\text { mengatasi masalah, setara } \\
\text { dengan orang lain, } \\
\text { menerima pujian tanpa } \\
\text { rasa malu, mampu } \\
\text { memperbaiki diri. }\end{array}$ \\
\hline 2 & $\begin{array}{l}\text { Karakteristik Psikologis: suka berbicara di depan } \\
\text { umum, sering bertanya daripada membuat } \\
\text { penyataan, sering berpikir apa yang dikatakan orang } \\
\text { lain, mendukung teman yang sukses, menjadi teman } \\
\text { setia daripada mengusulkan ide, mendapatkan ide } \\
\text { baru jika yang lama gagal, berani keluar untuk } \\
\text { modal usaha, bangkit ketika jatuh. }\end{array}$ & $\begin{array}{l}\text { Minat wirausaha: social } \\
\text { prestige, tantangan pribadi, } \\
\text { menjadi bos, inovasi, } \\
\text { kepemimpinan, fleksibilitas } \\
\text { dan keuntungan. }\end{array}$ \\
\hline 3 & $\begin{array}{l}\text { Karakteristik kontekstual: menjadi pemimpin yang } \\
\text { sukses, bertanggungjawab jika ada kerugian, } \\
\text { mengganti kerugian, berani meminta maaf secara } \\
\text { terbuka, yakin sukses berwirausaha, siap } \\
\text { kembangkan usaha, kesediaan menanggung resiko, } \\
\text { takut kehilangan uang Rp. } 100.000,--, \text { senang } \\
\text { dengan pelatiahan kewirausahaan, banyak tugas } \\
\text { kuliah malas wirausaha, sudah memiliki pemikiran } \\
\text { kreatif untuk wirausaha, sudah memiliki usaha, mata } \\
\text { kuliah wirausaha penting, mengajak orang untuk } \\
\text { mendapatkan penghasilan tambahan, bertekad } \\
\text { menjadi guru agama yang punya usaha sampingan. }\end{array}$ & $\begin{array}{l}\text { Ciri-ciri wirausaha: percaya } \\
\text { diri, berorientasi pada tugas } \\
\text { dan hasil, keberanian } \\
\text { mengambil keputusan, } \\
\text { kepemimpinan, keorisinilan } \\
\text { dan berorientasi masa } \\
\text { depan. }\end{array}$ \\
\hline
\end{tabular}

F. Temuan Faktor-faktor yang Mempengaruhi Jiwa Kewirausahaan Mahasiswa STPKat

Dari hasil analisis faktor-faktor yang mempengaruhi jiwa kewirausahaan mahasiswa dihasilkan temuan sebagai berikut:

a. Karakteristik demografi berupa umur dan status mempengaruhi terbentuknya jiwa kewirausahaan sebesar rata-rata 62\%. Ini dapat diartikan bahwa karakteristik demografi secara keseluruhan membawa dampak yang cukup untuk membentuk jiwa kewirausahaan. Munculnya nilai tersebut menandakan bahwa sebagian besar atau lebih dari 50\% dari seluruh mahasiswa dipengaruhi oleh pengalaman wirausaha keluarga atau kenalannya ketika mereka kecil sampai sekolah menengah atas. Selebihnya tidak ada indikasi pengaruh.

b. Karakteristik psikologis, dari pertanyaan sehubungan dengan sifat-sifat yang dimiliki oleh para mahasiswa antara lain dominating controller, 
cautious analyzer, supportive relaters, fun-loving promoters, diperoleh hasil nilai rata-rata $72 \%$. Ini dapat diartikan bahwa rata-rata sifat yang dimiliki mahasiswa mendukung pengembangan jiwa kewirausahaan. Nilai maksimal sebesar $85 \%$ (kategori sangat baik) terdapat pada sifat supportive relaters. Sifat supportive relaters adalah sifat yang suka mendukung teman yang sukses, menjadi teman yang setia, ceria, jarang mengusulkan ide atau bertanya.

c. Karakteristik kontekstual, faktor ini mendapatkan nilai rata-rata $82 \%$ (baik), Kesimpulan yang dapat ditarik dari karakteristik kontekstual ini adalah mahasiswa menghendaki jumlah pelatihan dan training kewirausahaan yang lebih banyak lagi. Faktor-faktor sikap dan kontekstual yang mempengaruhi mahasiswa STPKat dalam membentuk jiwa kewirausahaannya di saat mereka berkuliah dapat dijabarkan sebagai berikut:

i. Konsep Diri. Konsep diri mahasiswa STPKat saat ini adalah mereka mampu untuk memperbaiki diri dengan melakukan instrospeksi diri dan belajar dari kegagalan, serta mampu mengolah pujian tanpa rasa malu. Pujian-pujian dipakai sebagai koreksi untuk lebih maju dan berprestasi lagi. Konsep diri berikutnya adalah mereka tidak membeda-bedaan status sosial dalam pergaulan.

ii. Minat Berwirausaha. Minat berwirausaha mahasiswa STPKat dipengaruhi oleh factor-faktor berikut: (1) prestise sosial yang diartikan sebagai sebuah kebanggaan yang akan muncul dengan memiliki usaha bisnis sendiri; (2) keuntungan yang akan diraih; (3) tantangan pribadi jika orang lain bisa maka mereka juga harus bisa.

iii. Ciri-ciri Wirausahawan. Ciri-ciri wirausahawan yang dimiliki oleh mahasiswa STPKat adalah (1) kepemimpinan, tempat mereka bisa saling bekerjasama bersama dengan sesamanya, bersedia untuk dikritik oleh orang lain demi kemajuan dan keinginan untuk mencapai hasil; (2) berorientasi pada hasil yang mengandung usaha atau tujuan untuk memiliki atau memperoleh laba dengan tekad kerja keras dan ketekunan; dan (3) kepercayaan diri, mereka merasa berharga dan bangga terhadap diri sendiri, optimis, mengerti dan memahami kekuatan dan kelemahan diri sendiri. 


\section{DEKLARASI KEPENTINGAN}

Penelitian ini dilakukan demi perkembangan ilmu pengetahuan. Tidak ada konflik kepentingan maupun finansial dalam seluruh proses penelitian ini.

\section{PENDANAAN}

Sumber dana penelitian ini, berasal dari bantuan operasional pendidikan Dirjen Bimas Katolik, Kementerian Agama RI.

\section{PENUTUP}

Syukur kepada Tuhan atas pendampingan-Nya dalam penelitian ini. Terima kasih juga kami sampaikan kepada Kementerian Agama Bimas Katolik Jakarta; Fransisca Romana Wuriningsih M.Sc. Ed, ketua Sekolah Tinggi Pastoral Kateketik St. Fransiskus Asisi yang telah memberikan dukungan kepada kami sehingga penelitian ini terselesaikan; para Dosen STPKat St. Fransiskus Asisi Semarang yang telah memberikan kontribusi sumbang saran dalam penelitian ini; serta seluruh civitas akademika STPKat St. Fransiskus Asisi Semarang yang telah membantu dalam proses penelitian ini, baik pengisian kuesioner, maupun bantuan-bantuan teknis yang lain.

Semoga penelitian ini memiliki manfaat sebesar-besarnya bagi perkembangan kewirausahaan di STPKat, bagi kepentingan seluruh mahasiswa dan Dosen dan staff. Semoga niat baik kita selalu diberkati oleh Tuhan.

\section{REFERENSI}

Anwar, M. (2014). Pengantar Kewirausahaan Teori dan Aplikasi (ed. I). Jakarta: Prenadal

Lydianingtyas, D. D., Trijanto, D., \& Utoyo (2018). Kewirausahaan Teknik Sipil (ed. I). Malang: Polinema Press.

Dinar, M., dan Ahmad, I. S. (2020). Kewirausahaan. Bandung: CV Media Sains Indonesia.

Pieter, H. Z. (2017). Dasar-Dasar Komunikasi Bagi Perawat (ed. I). Jakarta: Kencana.

Handini, S., dan Sukesi, H. K. A. (2019). Pemberdayaan Masyarakat Desa Dalam Pengembangan UMKM di Wilayah Pesisir (N. Azizah (ed.)). Surabaya: 
Scopindo Media Utama.

Thomas W Zimmerer, N. R. S. (1998). Essentials of Entrepreneurship and Small Business Management. New Jersey: Prentice-Hall PTR.

Tontowi. (2016). Membangun Jiwa Entreprenuership (1st ed.). Malang: UB Press. Widaningsih, \& Ariyanti. (2018). Aspek Hukum Kewirausahaan (M. Abdu Rahmat Rosyadi, (ed.); 1st ed.). Malang: Polinema Press. 
Tentang Jurnal ini

Jurnal Penelitian Pendidikan Agama Katolik adalah jurnal nasional berbasis penelitian yang diterbitkan oleh organisasi profesi ilmiah untuk Pendidikan Agama Katolik, yakni Perhimpunan Perguruan Tinggi Agama Katolik Indonesia (PERPETAKI).

Artikel-artikel yang dimuat merupakan konversi hasil penelitian di bidang ilmu Pendidikan Agama Katolik.

Anggota dewan penyunting dan mitra bebestari berasal dari lebih daripada enam provinsi di Indonesia.

Jurnal ini terbit 2 (dua) kali setahun. Artikel-artikel ditulis dalam Bahasa Indonesia atau Bahasa Inggris.

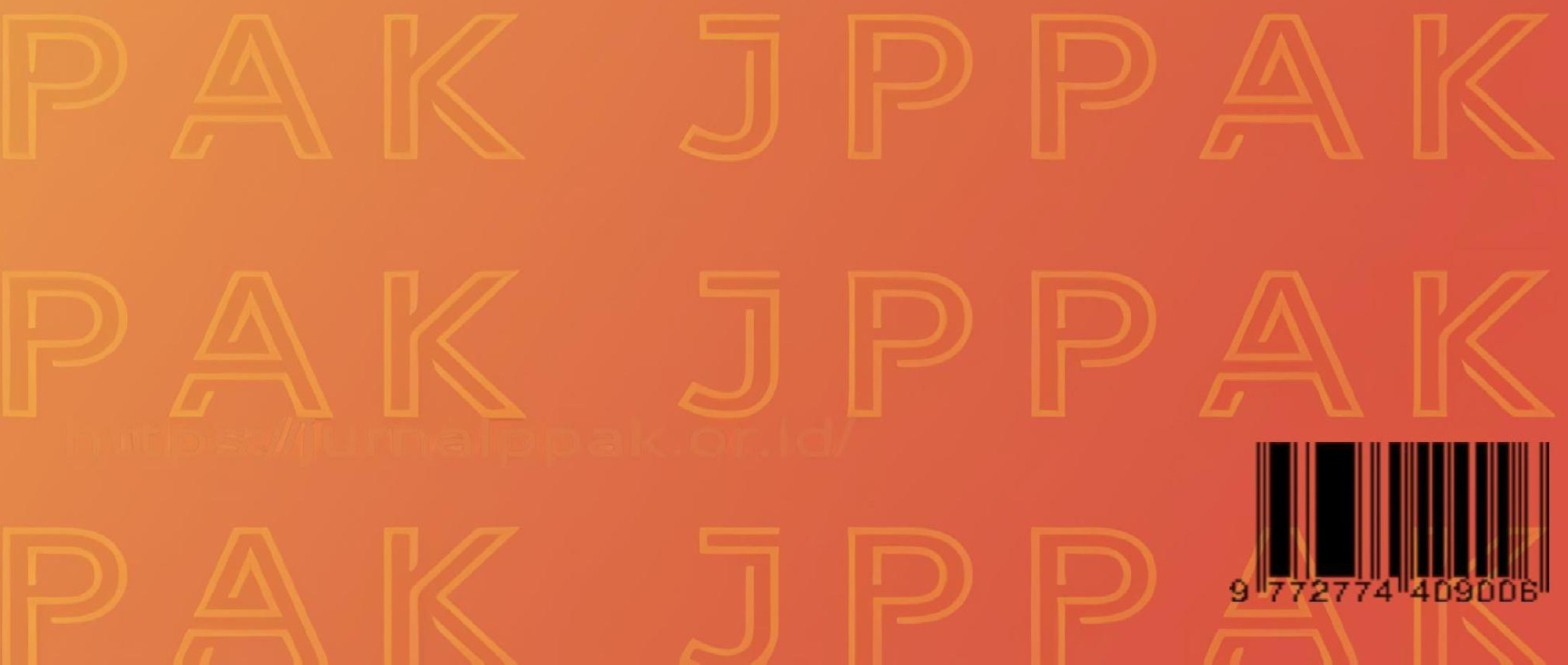

